\title{
Transhumanism and the Question of Human Nature
}

\author{
Gary Elkins
}

Humanities and Natural Sciences Department, Toccoa Falls College, Toccoa Falls, GA 30598, USA

\begin{abstract}
Transhumanism is the idea that we are at the brink of witnessing exponential changes in the way we understand the human species. Transhumanists believe that technology will make it possible, in the near future, to propel humanity to the next evolutionary stage, one in which defective human bodies will be replaced with more resilient hardware. The assumption is that humans are essentially information and that information can be uploaded, perhaps indefinitely, into machines. Not all transhumanists think alike, but my paper identifies several common tenets of transhumanism and presents a critique of the movement. I argue that transhumanism crosses an ethical line when it seeks to remake human nature. Indeed, it functions with a defective understanding of human nature because it wrongly assumes that the essence of a human can be reduced to information. Furthermore, I contend that if the goals of transhumanism are achieved, it will have a negative impact on humanity.
\end{abstract}

Keywords Transhumanism, Ray Kurzweil, Singularity, Human Nature

"Human nature will be the last part of Nature to surrender to Man. The battle will then be won. We shall...be henceforth free to make our species whatever we wish it to be. The battle will indeed be won. But who, precisely, will have won it? For the power of Man to make himself what he pleases means...the power of some men to make other men what they please."

C.S. Lewis, The Abolition of Man

(quoted in Joel Garreau, Radical Evolution)

"Modern technologies may be characterized as systematic attempts to master nature and human nature."

Brent Waters, From Human to Posthuman

\section{Introduction}

On June 24, 2010, the movie version of Ray Kurzweil's book, The Singularity is Near, premiered in New York. It is said that the singularity will occur when several technological events begin to converge in such a way that humans become "transhumans," or ultra-intelligent machines. Transhumanists envisage "an era in which the very nature of what it means to be human will be both enriched and challenged as our species breaks the shackles of its genetic legacy..." The technology that promises to usher in this promised utopia is just one component of a larger philosophical question about human nature. Indeed, as Joel Garreau, author of Radical Evolution observes, "The gee-whiz technology is just a window through which to gaze upon human nature." "ii Moreover, if transhumanists are

* Corresponding author:

gelkins@tfc.edu (Gary Elkins )

Published online at http://journal.sapub.org/ajis

Copyright (C) 2011 Scientific \& Academic Publishing. All Rights Reserved to be believed, the coming modifications to humans will bring about the transformation of human nature to the extent that future humans will hardly be recognizable. ${ }^{\text {iii }}$ Behind this prediction is the assumption that there is no unscalable wall between humans and machines. And transhumanists predict that exponential changes to human nature will happen very soon. ${ }^{\text {iv }}$ In less than 10 years, according to Kurzweil, humans will begin to realize that human intelligence is inferior to computer intelligence. And within 20 years, he expects that a $\$ 1,000$ unit of computation will have the capacity of 1,000 human brains i.e., 20,000 million billion calculations per second! ${ }^{\text {vi }}$ One proposed advantage to the advent of transhumanism is the creation of more resilient beings with the potential to long outlive feeble and ineffective human bodies. If transhumanists are right, there is no reason why human life (which consists of information as maintained by transhumanists), could not continue indefinitely once it has made the transition into machines. After all, even if the machine eventually breaks down, the information could be downloaded again into yet another machine ad infinitum.

Whatever one thinks about Kurzweil's lofty predictions about human transformation in the near future, the topic does raise questions about the essence of human nature, whether it is fixed or malleable, or perhaps both. Transhumanists deny that human nature has a permanent essence that endures throughout a person's lifetime and extends beyond death. Instead, transhumanists view Homo sapiens as a "work in progress" with the potential to be radically transformed by technology. But, what exactly is human nature? And, to what extent should science tamper with, enhance, improve upon, or seek to perfect humans? Furthermore, is there anything inherently wrong with the attempt to improve humanity? These are vitally important 
questions because, as J.P. Moreland reminds us, "Our view of a human person touches virtually every debated issue in bioethics today...,vii

In order to assess transhumanism, it is necessary to encapsulate some of transhumanism's central beliefs. In the following section, I will present what I take to be the seven core assumptions of transhumanism: 1) Humans are material beings, 2) human bodies are limited and defective, 3) natural evolution is too slow, 4) human nature is malleable, 5) the true essence of human nature is information, 6) there is no necessary distinction between humans and machines, and 7) information can be transferred to something more durable. Thereafter, I will offer a constructive critique of the movement.

\section{Seven Tenets of Transhumanism ${ }^{\text {vii }}$}

\subsection{Humans Are Material Beings.}

Transhumanists are materialists; they reject the notion that there is a spiritual component (e.g., a soul) to the physical body. Moreover, transhumanists "do not believe there is any soul that can survive the death of the body.",ix Yet, it is interesting to note that transhumanists are not completely reductionistic, i.e., the view that all mental activity can be reduced to functions of the brain. Brent Waters observes that posthumanist ${ }^{\mathrm{x}}$ anthropology is "paradoxically materialist and dualist (emphasis mine). In one respect, posthumanists are thoroughgoing materialists...But they are also dualists in that they believe that a life of the mind exists, to a large extent, independently of, or despite, the material limitations of the body in which it is encased."

Ted Peters also notes that "Curiously, the assumption at work in transhumanism is that human intelligence and human personhood can become disembodied (emphasis mine)."xii This, of course, does not mean that transhumanists are dualists in the traditional sense. ${ }^{\text {xiii }}$ Rather, transhumanists believe that it is only the brain's information that becomes "disembodied" and subsequently transferred into a machine. In any case, transhumanists start with the assumption that the human body consists of matter and information, information that can be transferred into something perhaps more durable than the physical body.

\subsection{The human Body, In Its Current Form, Is Limited and Defective}

Transhumanists believe that humans represent the current apex of natural selection. But transhumanists also desire to become posthuman. Waters notes that what unites the proponents of transhumanism, "is an unwavering belief that the current state of the human condition is deplorable, and the only effective way to remedy this plight is for humans to use various technologies to radically enhance and transcend their innate and latent capabilities."xiv When asked to define the human, Kurzweil replies that the human is "that species that seeks to extend its own horizons - that represents the cutting edge of evolution." ${ }^{\text {xv }}$ In fact, transhumanist goals are not modest but far-reaching to the extent of completely redefining what it means to be human. That is, they are not content with the current human body with all its limitations; they think it is both possible and desirable to make significant improvements to the human body. ${ }^{\text {xvi }}$ Science journalist Brian Alexander remarks that, "Transhumans regard our bodies as sadly inadequate... which restricts our brain power, our strength and, worst of all, our life span."xvii Kurzweil agrees; hence, we need to become "less biological" and more technologically enhanced, more "God-like.,"xviii

\subsection{The Process of Evolution Is Too Slow}

The evolutionary process itself takes time, too much time, in fact. As Waters explains it, transhumanists believe that humans are a "work-in-progress" but remain "half-baked" and require "more cooking."xix "The problem," writes Waters, "is that, given biological limitations, humans do not have enough time (emphasis mine) to be sufficiently cooked, thereby restricting their improvements as individuals and a species." ${ }^{\text {xx }}$ The human body, as far as science can determine, has not significantly changed over the last 100,000 years, at least genetically speaking. ${ }^{\text {xi }}$ At that rate, transhumanists do not hold out much hope that natural evolution will produce the necessary improvements at a faster pace. Thus, transhumanists believe that it is time for humans to take matters into their own hands in order to speed up the advance of human evolution.

\subsection{Human Nature Is Malleable, Not Static}

"The central argument about the future of human nature," remarks Garreau, "is whether it is fixed and immutable, once and forever, or whether it can continue to evolve."xxii Indeed, this is the crux of the matter. On the one hand, if humans have an unchanging essence that is irrevocably part of what it means to be a human, then no amount of technology will alter this. On the other hand, if the body is merely a container of information that has been constructed and deconstructed over time by external forces, then what is to prevent this process to continue into the future? Transhumanists prefer the latter view; there is nothing permanent about human nature. Garreau quotes FernandezArmesto, who opines, "Human nature...is not fixed; it has changed in the past and could change again.... How much our nature has to change before our descendants cease to be human is a question we are not yet ready to answer.... That humans are uniquely rational, intellectual, spiritual, selfaware, creative, conscientious, moral or godlike seems to be a myth (emphasis mine) - an article of faith to which we cling in defiance of the evidence."xxiii

Ted Peters reminds us that the assumption of a permanent human identity does not accompany the vision of transhumanism. xxiv "Human nature," Garreau declares, "is not etched in stone." $\mathbf{x v}$ Waters comments that from a 
transhumanist perspective, "There are no given features, such as finitude and mortality, which define the quality and character of human life and lives. Personal, social and political identities are subjected to continuous deconstruction and reconstruction. In this respect, medicine (and I would add 'technology') can be used to deconstruct and reconstruct human bodies." $x x v i$

The assumption is that if it is possible for humans to be radically transformed, so much so that there remains little resemblance to current humans, then it stands to reason that human nature itself is not fixed, but can be subject to technological transformation.

\subsection{The True Essence of Human Nature Is Information}

If a human does not have a fixed essence or nature, then what exactly allows it to function besides mere biological processes? Part of the answer, according to transhumanism, is information (also referred to nonbiological intelligence). ${ }^{\mathbf{x} v i i}$ Digital information is essentially what passes between humans and computers; it allows "communication" to occur in a meaningful manner. As technology advances, interaction with, and dependence on, computers has increased. Kurzweil foresees the time when computers are "embedded everywhere - in your walls, tables, desks, clothing and body." "xxiii In fact, keyboards, cables and even printed documents will become a thing of the past, he predicts. In this world, there will no longer be a sharp demarcation between humans and machines. ${ }^{\text {xix }}$ Waters, referring to the thought of Elaine Graham, ${ }^{\mathbf{x x x}}$ writes, "What constitutes human life...can be reduced to patterns of information that, with the aid of ever more sophisticated technology, can be manipulated into virtually limitless configurations." "xxi Neural implants of computer chips will allow information to be transferred directly into a machine. Garreau explains, "In this world, humans exist who are machine based. They no longer have neurons, flesh or blood. They don't have 'wetware.' Instead, their brains are based on electronic and photonic equivalents. That's because the human brain has been reversed-engineered. It has been fully scanned, analyzed, understood and translated into machine analogues."xxxii

The basic assumption is that what we call the "mind" is actually defined by information, data that can be uploaded from the brain in order to be downloaded into a machine. "We are," notes Peters of transhumanism, "what we think." "xxiii As the website Lifeboat Foundation explains it, "people don't want to think that they're "just" data structures being implemented as computational automata on biological neurons. But it is hard to think of it any other way: once we dismiss the possibility of an immaterial soul, we must acknowledge the mind as a material pattern implemented in physical configurations, and if other substances aside from our current neurons can meet the requirements for these configurations, then there is no reason why intelligence and consciousness could not exist on another substrate."
In short, the human body is matter and the "mind" consists merely of data structures. As Waters observes, "A cybernetic paradigm reduces material reality to underlying information that can, in principle, be infinitely manipulated and reconfigured." ${ }^{\mathbf{x x v}}$ And if the mind consists of data, then there is no reason why that data cannot be transferred to another "substrate." Or, to state the matter differently, "the only thing preventing a radical transformation of nature and human nature is inadequate technology.",xxxvi

Furthermore, the "person" experiencing the transfer will not notice any significant difference between his biological brain and the synthetic brain. This is because, "The brain can't tell if it's made out of traditional meat, or accelerated biological neurons, or entirely nonbiological neuronequivalents: the computation is the same." xxxvii Indeed, some believe that the process could even be reversed; the information could again be uploaded from the machine and downloaded into a human-created molecular entity. ${ }^{\text {xxxviii }}$ Ultimately, the "goal is to achieve virtual immortality," by "uploading the mind which can then be downloaded into" more permanent structures. ${ }^{\text {xxix }}$ Or, as described by Peters, The goal of transhumanism is to download the contents of human consciousness onto a vast computer network and... achieve a kind of disembodied yet intelligent immortality...AI researchers will reduce existing human intelligence to a pattern of information processing and download this into a computer or robot. This will constitute an evolutionary advance... that could lead to immortality that is, immortal intelligent life in a machine that gets constant back-ups. ${ }^{\mathbf{x}}$

\subsection{There Is No Necessary Distinction between Humans and Machines}

The geneticist Craig Venter was recently asked to reflect on the philosophical importance of his effort to create synthetic life in a laboratory. His response, "It certainly changed my view of the definition of life, and how dynamic the cells are, and that we are biological machines driven by software (emphasis mine)." that this is possible means bacterial cells are softwaredriven biological machines. If you change the software, you build a new machine." ${ }^{\text {xlii }}$ Whether Venter considers himself a transhumanist is not clear. What is evident, however, is his affirmation of the notion that humans are biological machines. Transhumanists also view humans as biological machines, machines that contain transferable information. According to N. Katherine Hayles, , xlii "the manner in which organisms and machines process and exchange information mirrors each other, raising the prospect...that the line separating the organic from the mechanistic can be removed...." ${ }^{\text {xliv }}$ In truth, if the information in our brains can be transferred to other machines, then, as science fiction writer Damien Broderick queries, “....what is to prevent us from copying - mapping - our neurological complexity into some more durable, swifter material substrate?"xlv The process could be compared to uploading the information in 
the brain in order to download the information into a more durable machine.

\subsection{Information Can Be Transferred Into Something More Durable}

Peter Manley Scott and Celia Deane-Drummond explain that the "...task of transhumanism is...to find a different medium than our bodies in which or cognitive functioning may continue (indefinitely?)." ${ }^{\text {,lvi }}$ Moreover, declares physicist Frank Tipler, "We will create computers in our image, and these computers in turn will create a replica of ourselves; and this replica will persist beyond our death and beyond the death of the universe." "xlvii

When the transfer occurs, this will produce a transhuman. Kurzweil predicts that "humanity is fast approaching an era in which our intelligence will become trillions of times more powerful and increasingly merged with computers. This will be the dawning of a new civilization, enabling us to transcend our biological limitations. In Kurzweil's postbiological world, boundaries blur between human and machine, real and virtual. Human aging and illness are reversed, world hunger and poverty are solved, and we cure death."

Some thinkers imagine a world where there is a distinction between the "Naturals" and the "Enhanced." In this world, "Naturals," i.e., those who have not received genetic enhancements, may be viewed as if they are disabled because they simply cannot keep up with those who are genetically superior. ${ }^{\text {xlviii }}$ Others describe the next possible step - the Singularity - when machines begin to outperform the intelligence of humans to such an extent that they become "ultra-intelligent" and begin to replicate themselves. ${ }^{\text {xlix }}$ Unfortunately, as Waters warns, "The price for this radical transformation is the disappearance of humans as embodied creatures." Transhumanists are not troubled by such a scenario; the departure of the human is something to celebrate.

\section{A Critical Response to Transhumanism}

At this point it would be beneficial to mention a logical fallacy known as the "drawing-the line fallacy." The drawing-the-line fallacy says that although a precise line cannot be drawn between two options, nonetheless, a distinction between the two options can be made. Thus, one could argue that, although one cannot draw a precise line between efforts to either treat or cure a disease, and attempts to genetically enhance or even replicate humans, this does not mean that a difference cannot be made. Peters makes a useful distinction between therapy, enhancement and transhumanism. 'Therapy' is the common term used in the practice of medicine. The general goal of therapy is, if possible, to restore a person's health. ${ }^{\mathrm{li}}$ In other words, "To be healthy... is to exist at the norm, to live as our bodies were originally designed to live."lii 'Enhancement' is the attempt to improve the human condition to the level of excellence, beyond what it considered "normal." Eric Juengst defines enhancement as intervention "designed to improve human form or functioning beyond what is necessary to sustain or restore good health."liii

Whether there are "treatments" that blur the line between therapy and enhancement is not the subject of this paper. However, I believe that a clearer distinction can be made between therapy and 'transhumanism.' Transhumanism is not content with enhancement; it seeks to "remake human nature."liv The goal is to extend human life, even to the point of immortality. As Peters describes it, for transhumanists, "death should become voluntary. Immortality should become an option. Once we advance to the posthuman future, we will no longer be required to die. Immortality will belong to our definition as posthumans.",lv

The main tenets of transhumanism, specifically 4,5 , and 6 , relate to the philosophical question of human nature. The concern, of course, is that if human nature is indeed malleable and transferable, if humans are essentially information, and if there is no actual distinction between humans and machines, then what does the future hold for humanity? While it may be interesting to speculate on this question, a more profitable venture would be to present an alternative account of human nature.

In response to the question of whether human nature is fixed or malleable, one possible rejoinder is both. In other words, could it be that some psychological and experiential features $^{\text {Ivi }}$ of human nature are subject to change while personal identity is kept intact? It is common to shift from one emotion to another or to change one's mind about something. This does not mean that a person has changed into another identity. Peters writes, "...changes in the body, even if resulting in changes in the mind, do not risk a loss of identity. Beyond the therapy and even beyond the enhancement, our transformed self will still be our self."lvii The common sense understanding of human identity, the view that best fits human experience is one that posits the continuity of an individual's identity i.e., an individual remains the same individual throughout his existence. This continuity cannot be explained by simply reducing human nature to mere information.

In addition, a strong case could be made that the continuity of identity can only be explained by putting forward a robust description of human nature, one that accounts for the common experiences of self-awareness, memory, the ability to identify people, places, etc. and the capacity to engage in self-reflection. Also, the psychological powers to think, be aware of, choose, reflect, experience (pleasure and pain, emotions), and the like, are consistent with the view that a personal agent, and not simply information, is involved. If human nature consists merely of information, then how are we to account for these common experiences? Actually, it is more natural and intuitive to make reference to "you" acting in such and such 
a way, rather than to suggest that information is responsible for your actions. In sum, the view that human nature is merely information leaves too many matters unexplained. Then there is the matter of consciousness. John Searle ${ }^{\text {lviii }}$ is noted for having a deep appreciation for the complexities of consciousness. He questions how "consciousness can be reduced to zeroes and ones, that there is not some deep mystery behind it." ${ }^{\text {,lix }}$ Indeed, human consciousness itself is difficult to explain if humans are reduced to transferable data.

Transhumanism, the philosophy that drives it, and its actual fulfillment, will negatively impact humanity in at least two areas: the dehumanization of humans, and the unavoidable but dangerous distinction between the "Naturals" and the "Enhanced."

First, a strong case can be made that, by forfeiting the negative traits that make us human (in our current form), we lose the potential positive qualities that result from difficult life experiences. Francis Fukuyama comments that, "Human nature exists, is a meaningful concept, and has provided a stable continuity to our experience as species." It is, "with religion, what defines our most basic values." But in the transhumanist world, we "no longer struggle, aspire, love, feel pain, make difficult moral choices, have families, or do any of the things that we traditionally associate with being human." Consequently, we "no longer have the characteristics that give us human dignity." $\mathrm{px}$ He continues: Even something like the elimination of pain and suffering.... There's something about the experience of pain and longing and anxiety and all of these things that our therapeutic society is trying to get rid of. It is somehow necessary to our self-understanding of what we are as human beings. I mean, you can't have courage without risk. You can't have real compassion or sympathy without the personal experience of pain. ${ }^{\text {xi }}$

Human nature provides us with a sense of morality as well as the ability to make moral, social and creative choices. It allows humans to dialog with each other about issues pertaining to justice, autonomy, human rights, politics and, ironically, whether transhumanism is a good idea. Waters continues this sentiment by summarizing Leon Kass' perspective, "It is in coming to terms with their finite limits, and the inherent pain and suffering entailed in those limits, that humans embody the nobility of spirit that is supremely expressed in procreation."

British neuroscientist Susan Greenfield adds that, in the end, humans will lose their individuality and personal identity. ${ }^{\text {xiii }}$ They will lose the will to achieve because achievement will be built into the technology. Perhaps the worst facet of the transhumanist scenario is that, if the successful transfer to machines occurs, then humans won't know that they are dehumanized, nor will they care to know it. ${ }^{\text {lxiv }}$

Additionally, the rise of transhumans will inevitably leave some humans behind. Fukuyama believes that the separation between "Naturals" and the "Enhanced" will be so deep that it will make all other divisions based on religion or race seem insignificant in comparison. He thinks that it would result in a "full-scale class war." question whether there is any track record of long term civility in the history of humankind to indicate that we will avoid life-threatening conflict between radically divergent species. Greenfield reminds us of Bertrand Russell's sentiment: "Science has not given men more self-control, more kindliness, or more power of discounting their passions...Men's collective passions are mainly for evil; far the strongest of them are hatred and rivalry directed toward other groups." ${ }^{\text {,kvi }}$

\section{Conclusions}

In conclusion, transhumanism, as well as those who identify with its goals, is fueled by technological hubris. As Waters observes that, "The history of the world [is] not an account of creation being drawn mysteriously to a destiny assigned by its creator, but an unfolding tale of human potential and capability." "Ixvii But Martin Rees questions whether any precautions are taken into consideration with advancing technologies. Simply put, "humans should not create something new unless they are reasonably certain

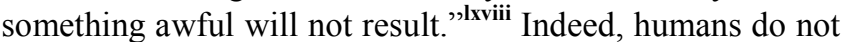
have a very good track record of taking care of themselves. I am inclined to agree with Bill Joy that we are more likely to instigate the "Hell Scenario" horrific events begin to unfold.

\section{REFERENCES}

[1] Gary S. Elkins, Ph.D. Philosophy - University College Dublin, Ireland, 1999

[2] M. A. - Bioethics, Trinity Graduate School, 2010

[3] Recent articles and research: Published in Ethics and Medicine, An International Journal of Bioethics, Fall, 2010, "Sacred Cells? A Reply to Peters, Lebacqz and Bennett"

[4] Research papers (unpublished): "Liberal Communitarianism and the Physician's Rights of Conscience" submitted to Dr. C. Ben Mitchell on May 3, 2010

[5] "An Assessment Of Two Key Principles Found In Ezekiel Emanuel's Health Care Policy" submitted to Dr. Ferdinand Yates on September 14, 2009

[6] "Recent Developments in Stem Cell Research" submitted to Dr. Michael Sleasman on September 28, 2008

[7] "When Death Occurs and Why It Matters" submitted to Dr. Michael Sleasman on September 28, 2008

${ }^{i}$ The Singularity is Near, Movie Home,

http://www.singularity.com/themovie/index.php (Accessed July 23, 2010).

ii Joel Garreau, Radical Evolution (New York, Broadway Books, 2005) 4. 
iii Ibid., 11.

${ }^{\text {iv }}$ By 2030, as stated by Kurzweil. Ibid., 103.

${ }^{v}$ Currently computer intelligence is considered to be much inferior to human intelligence.

vi Ibid., 100-101.

vii J.P. Moreland and Scott B. Rae, Body and Soul, (Downers Grove, Il., InterVarsity Press, 2000) 236.

viii I do not want to imply that transhumanists always speak with one voice on these matters. Brent Waters writes that "Transhumanism is a multifaceted and ill-defined movement...a transitional movement dedicated to transforming humans into posthumans." Brent Waters, From Human to Posthuman (Hampshire, England, Ashgate Publishing Limited, 2006) 50.

${ }^{\text {ix }}$ Celia Deane-Drummond and Peter Manley Scott, Future Perfect? God, Medicine and Human Dignity (New York, NY, T \& T Clark, 2010) 190.

x Posthumanism' is a broader category to designate humanity after the emergence of transhumans.

xi Ibid., 192.

xii Ibid., 25.

xiii I.e., Either Cartesian dualism or substance dualism.

${ }^{\text {xiv }}$ Waters, 50.

${ }^{x v}$ Garreau, 127.

xvi Deane-Drummond and Scott, 2.

xvii Ibid., 25.

xviii Garreau, 127-129.

xix Deane-Drummond and Scott, 191-192.

xx Ibid., 192.

xxi Garreau, 239.

xxii Ibid., 235.

xxiii Ibid., 239.

xxiv Deane-Drummond and Scott, 25.

${ }^{\mathbf{x x v}}$ Garreau, 108.

xxvi Deane-Drummond and Scott, 186.

${ }^{\text {xxvii }}$ Lifeboat Foundation, http://lifeboat.com/ex/transhumanist.technologies\#2 (accessed July 30, 2010).

xxviii Garreau, 99.

${ }^{\text {xxix }}$ Ibid., 99-102.

${ }^{\mathbf{x x x}}$ Research professor of the University of Chester.

xxxi Deane-Drummond and Scott, 186.

xxxii Garreau, 104.

xxxiii Deane-Drummond and Scott, 18.

${ }^{\text {xxxiv }}$ Lifeboat Foundation, http://lifeboat.com/ex/transhumanist.technologies\#2 (accessed July 30, 2010).

${ }^{\mathbf{x x x}}$ Waters, ix.

xxxvi Ibid., $\mathrm{x}$.

xxxvii Lifeboat Foundation, http://lifeboat.com/ex/transhumanist.technologies\#2 (accessed July 30, 2010). xxxviii Ibid., http://lifeboat.com/ex/transhumanist.technologies\#2 (accessed July 30, 2010).

xxxix Waters, 50 .

${ }^{\mathrm{xl}}$ Deane-Drummond and Scott, 19.

xli Sam Gale Rosen, On Point, Craig Venter: "We are Biological Machines, Driven by Software" http://www.onpointradio.org/2010/05/craig-venter (accessed July 31, 2010).

xlii The Design Matrix, http://designmatrix.wordpress.com/2010/06/03/venterand-synthetic-life/ (accessed July 31, 2010).

xliii Author of "How We Became Posthuman." Cited in Waters, From Human to Posthuman, 40.

xliv Waters, 40.

${ }^{\text {xlv }}$ C. Ben Mitchell, Edmund D. Pellegrino, Jean Bethke Eishtain, John F. Kilner, and Scott Rae, Biotechnology and the Human Good (Washington, DC, Georgetown University Press, 2007) 43.

xlvi Deane-Drummond and Scott, 2.

xlvii Ibid., 26.

xlviii Garreau, 8.

xlix Ibid., 73.

${ }^{1}$ Waters, 64.

lii Health' is defined by the World Health Organization as "a state of complete physical, mental, and social well-being (not merely the absence of disease)." See "Perfect Humans or Enhancement" in Future Perfect, 17.

lii Deane-Drummond and Scott, 17.

liii Ibid., 17.

liv Ibid., 18.

Iv Ibid., 18.

lvi E.g., moods, emotions, intentions, desires, thoughts, sensations, etc.

Ivii Deane-Drummond and Scott, 25.

Iviii Professor of philosophy (philosophy of mind) at the University of California, Berkeley.

${ }^{\text {lix }}$ Garreau, 177.

${ }^{\text {lx }}$ Garreau, 155.

Ixi Ibid., 162,

Ixii Waters, 65 .

Ixiii Ibid., 168.

Ixiv Garreau, 155. Unfortunately, Fukuyama is hard-pressed to define human nature; he refers to the essence of human nature as "Factor X."

Ixv Ibid., 162.

Ixvi Garreau, 169.

Ixvii Waters, 11.

Ixviii Garreau, 167.

Ixix Ibid., The 'Hell scenario' is described in chapter 5, 135185. 